\title{
Penyakit Adamantiades-Behcet Koinfeksi dengan Herpes Genital
}

\author{
${ }^{1}$ Charly M. M. Korompis, ${ }^{1}$ Triomega F. X. Sengkey, ${ }^{2}$ Shienty Gaspersz, ${ }^{2}$ Nurdjannah \\ J. Niode
}

\author{
${ }^{1}$ PPDS Bagian Ilmu Kesehatan Kulit dan Kelamin Fakultas Kedokteran Universitas Sam \\ Ratulangi Manado \\ ${ }^{2}$ Bagian/KSM Ilmu Kesehatan Kulit dan Kelamin Fakultas Kedokteran Universitas Sam \\ Ratulangi/RSUP Prof. Dr. R. D. Kandou Manado \\ Email: charly-melan@yahoo.com
}

\begin{abstract}
Adamantiades-Behcet (AB) disease is a rare multi-systemic inflammatory disorder with unknown cause. It is characterized by recurrent mucocutaneous ulcer in the mouth and genitalia, and mostly affects the age group of 20 to 30 ys. Genital lesion of AB must be differentiated from others caused by sexually transmitted disease, such as genital herpes. Coinfection of $\mathrm{AB}$ with genital herpes is very rare. We reported a male 72-year old, came with painful ulcers in the mouth and genital area since a week before visit. Symptoms were recurrent since three years ago. History of arthritis, recurrent headache, eye and skin lesions were denied. Patient was sexually promiscuous. Physical examination revealed multiple ulcers on the labium oris sized $0.5 \mathrm{~cm}-1 \mathrm{~cm}$, irregular border, base covered by fibrin tissue, associated with erosion and crust. Multiple ulcers were also found on penile glans, sized $0.1 \times 1 \times 0.2 \mathrm{~cm}$, irregular border, with pus and necrotic tissue. The ulcers were punched out. Pathergy test and anti HSV-1 IgM were negative meanwhile anti HSV-1 IgG, anti HSV-2 IgM as well as anti HSV-2 IgG were positive. Acyclovir 200mg 5x/day for five days, triamcinolone acetonide lotion bid for the mouth ulcer, $\mathrm{NaCl} 0,9 \%$ dressing applied tid for 30 minutes, and fucidic acid cream bid were given and the symptoms improved after 10 days. The prognosis was bonam for ad vitam and dubia for ad functionam and ad sanationam. Conclusion: The diagnosis of $\mathrm{AB}$ was based on the International Criteria for Behcet Disease, with a total score of 4 for the recurrent ulcer in mouth and genital area. The positive result of anti HSV-1 IgG, anti HSV-2 IgM and anti HSV-2 IgG supported the coinfection with genital herpes. This coinfection of $\mathrm{AB}$ and genital herpes was the first reported in Manado. Immunosenescence was a possible risk factor of the recurrent genital herpes. Symptomatic and antiviral treatment improved the symptoms with possible recurrent genital herpes.
\end{abstract}

Keywords: Adamantiades-Behcet, genital herpes, coinfection

\begin{abstract}
Abstrak: Penyakit Adamantiades-Behçet (AB) merupakan kelainan inflamasi multisistemik yang tidak diketahui penyebabnya dengan manifestasi mukokutan tersering berupa ulkus berulang pada mulut dan genital. Penyakit ini terutama terjadi pada usia 20-30an. Lesi genital pada $\mathrm{AB}$ perlu dibedakan dengan ulkus genital akibat infeksi menular seksual termasuk herpes genitalis. Koinfeksi AB dan herpes genitalis jarang terjadi. Kami melaporkan kasus seorang laki-laki, usia 72 tahun, dengan keluhan luka di bibir dan kelamin yang nyeri sejak 1 minggu lalu, bersifat hilang-timbul selama 3 tahun terakhir. Riwayat nyeri sendi, sakit kepala berulang, serta kelainan kulit disangkal. Terdapat riwayat promiskuitas yang tinggi. Pada pemeriksaan fisik di regio labialis oris ditemukan ulkus multipel, diameter $\pm 0,5-1 \mathrm{~cm}$, tepi tidak teratur, dasar tertutup jaringan fibrin, dengan erosi dan krusta. Di regio glans penis ditemukan ulkus multipel, ukuran bervariasi $\pm 1 \times 2 \times 0,2 \mathrm{~cm}$, tepi tidak teratur, dasar tertutup pus dan jaringan nekrotik, terdapat punch out dan erosi. Tes patergi negatif. Pemeriksaan anti HSV-1 IgM (-), anti HSV-1 IgG (+), anti HSV-2 IgM dan IgG (+). Terapi asiklovir 5 x 200 $\mathrm{mg}$ /hari selama 5 hari, salep triamsinolon asetonid 2 kali oles, kompres terbuka $\mathrm{NaCl} 0,9 \% 3 \mathrm{x}$
\end{abstract}


30 menit/hari, krim asam fusidat 2 kali oles, memberikan perbaikan klinis setelah 10 hari pengobatan. Prognosis quo ad vitam bonam, quo ad functionam, quo ad sanationam ad dubia. Simpulan: Pada kasus ini, diagnosis AB ditegakkan berdasarkan International Criteria for Behcet Disease yaitu ditemukannya ulkus berulang di mulut dan di genital, masing-masing mendapat nilai 2, sehingga nilai total ialah 4. Ditemukannya anti HSV-1 IgG, anti HSV-2 IgG dan IgM positif, menunjang diagnosis tambahan herpes genital (rekuren). Koinfeksi AB dengan herpes genital baru pertama kali dijumpai di Manado. Keadaan immunosenescence kemungkinan menjadi faktor pencetus terjadinya rekurensi herpes genital. Pasien sembuh dengan terapi simtomatis dan antivirus, meskipun kemungkinan rekurensi dapat terjadi lagi.

Kata kunci: Adamantiades-Behcet, herpes genital, koinfeksi

Penyakit Adamantiades-Behçet (AB) merupakan kelainan inflamasi sistemik yang belum diketahui penyebabnya dan diklasifikasikan sebagai vaskulitis sistemik pada semua tipe dan bentuk pembuluh darah. ${ }^{1}$ Penyakit ini biasanya terjadi pada dekade ketiga baik pada laki-laki maupun perempuan, namun dapat juga terjadi pada usia muda atau tua. ${ }^{2}$ Etiopatogenesis AB masih belum diketahui, diduga berhubungan dengan faktor genetik. ${ }^{1,3}$ Diagnosis AB ditegakkan berdasarkan International Criteria for Behçet Disease (ICBD), dengan menilai lesi berulang di mata, mulut, genital, kulit, serta tes patergi. Bila skor $\geq 4$ maka diagnosis $\mathrm{AB}$ dapat ditegakkan., ${ }^{1,5}$

Herpes genitalis tergolong infeksi menular seksual yang disebabkan oleh Herpes simplex virus (HSV) terutama tipe 2 , dapat juga oleh tipe 1. Gejala khas berupa vesikel atau erosi berkelompok dengan dasar eritema, dan bersifat rekuren. ${ }^{6-8}$ Bila seseorang terpajan HSV, maka infeksi dapat berbentuk episode I infeksi primer (inisial), episode I non-infeksi primer, infeksi rekuren, dan asimtomatik. Infeksi rekuren biasanya terjadi karena adanya faktor pencetus sehingga virus mengalami reaktivasi dan multiplikasi kembali dengan kelainan klinis yang tidak seberat infeksi primer. ${ }^{8}$

Imunitas pejamu, terutama sistem imunitas seluler, berperan penting terhadap risiko infeksi, derajat penyakit, dan risiko rekurensi HSV. ${ }^{9,10}$ Pada usia lanjut terjadi penurunan berbagai fungsi fisiologik termasuk sistem imun seluler dan humoral secara bertahap sebagai akibat proses penuaan (immunosenescence) yang dapat memengaruhi manifestasi klinis dan rekurensi infeksi HSV. ${ }^{11}$ Manifestasi klinis biasanya didahului rasa terbakar dan gatal di daerah lesi yang terjadi beberapa jam sebelum timbulnya lesi. Lesi pada kulit berbentuk vesikel berkelompok dengan dasar eritem. Vesikel mudah pecah dan menimbulkan erosi multipel. Timbulnya lesi dapat disertai dengan gejala konstitusional berupa demam, malaise, dan nyeri otot. ${ }^{8}$ Beberapa pemeriksaan penunjang yang tersedia antara lain tes Tzank dan pemeriksaan serologik. ${ }^{7}$

Sepengetahuan penulis, kejadian koinfeksi antara $\mathrm{AB}$ dengan herpes genitalis rekuren belum pernah dilaporkan. Berikut ini dilaporkan satu kasus AdamantiadesBehçet koinfeksi dengan herpes genitalis rekuren pada seorang pasien laki-laki berusia 72 tahun.

\section{LAPORAN KASUS}

Seorang laki-laki, berusia 72 tahun dikonsultasikan ke Bagian Kulit dan Kelamin dari Bagian Penyakit Dalam RSUP Prof. Dr. R. D. Kandou dengan keluhan utama luka-luka di mulut dan kelamin yang terasa nyeri.

Berdasarkan anamnesis didapatkan luka-luka di dalam mulut dan kelamin yang nyeri dialami sejak 1 minggu lalu yang timbulnya hampir bersamaan. Terdapat riwayat demam sebelum timbul luka. Pasien mengeluh sulit makan karena lukaluka di mulut terasa nyeri dan badan menjadi lemas. Keluhan luka pada mulut dan kelamin ini sudah dialami 4 kali sejak 3 tahun terakhir dan keduanya hampir selalu bersamaan. Riwayat timbul lepuhlepuh di mulut atau di kelamin saja sebelumnya, disangkal pasien. Riwayat 
gangguan penglihatan sebelumnya diakui pasien, tetapi sudah dilakukan operasi katarak. Riwayat nyeri sendi disangkal. Pasien beberapa kali berobat ke dokter untuk keluhan ini, membaik setelah diberikan pengobatan berupa obat minum dan obat oles (pasien lupa nama obatnya) tetapi kambuh lagi.

Status pernikahan yaitu pasien sudah 3 kali menikah. Istri dari pernikahan ke-1 sudah cerai; istri dari pernikahan ke-2 sudah meninggal; dan isteri dari pernikahan yang ke-3 sudah meninggal 10 tahun yang lalu. Mengenai rwayat seksual, hubungan seksual terakhir 10 tahun yang lalu dengan istri ke-3 secara kelamin-kelamin tanpa menggunakan kondom. Riwayat hubungan seksual oro-genital dengan istri tidak ada. Terdapat riwayat hubungan seksual selain dengan istri (beberapa pasangan seks yang berlawanan jenis). Pada riwayat penyakit dahulu, pasien memiliki riwayat sakit darah tinggi dan kencing manis sejak 3 tahun terakhir dan berobat teratur. Terdapat juga riwayat penyakit ginjal 1 bulan terakhir. Mengenai riwayat keluarga, hanya pasien yang sakit seperti ini. Riwayat alergi makanan dan obat-obatan disangkal. Riwayat atopi yaitu bersin-bersin pagi hari, alergi debu dan riwayat asma disangkal. Riwayat sosial ekonomi dan kebiasaan yaitu pasien sudah pensiun dari pekerjaan sebagai ABRI, dan aktivitas sehari-hari mengikuti kegiatan kemasyarakatan.

Pada pemeriksaan fisik didapatkan status generalis yaitu keadaan umum tampak sakit, kesadaran kompos mentis, tanda vital dalam batas normal; kepala, leher, toraks, abomen, ekstremitas dalam batas normal. Pada status dermatologis didapatkan regio labialis oris dengan ulkus multipel, berbentuk bulat, diameter $\pm 0,5-1$ $\mathrm{cm}$, batas tegas, dan dasar tertutup jaringan fibrin. Sekitar ulkus tampak kemerahan, dengan erosi dan krusta. Generalisata tidak didapatkan purpura. Pada status venereologis didapatkam regio glans penis dengan ulkus dangkal, multipel, berbentuk tidak beraturan, ukuran bervariasi $\pm 1 \times 2 \times 0,2 \mathrm{~cm}$, lesi dengan punch out dan erosi. Sebelumnya terdapat vesikel berisi cairan jernih, berkelompok, disertai erosi (Gambar 1).

Pemeriksaan penunjang yang dilakukan ialah pemeriksaan laboratorium yang mendapatkan leukositosis $10.720 / \mu \mathrm{L}$, eritrosit $2,89.10^{6}$ juta $\mu \mathrm{L}$, hemoglobin 9,7 $\mathrm{g} / \mathrm{dL}$, hematokrit $28,0 \%$, ureum $93 \mathrm{mg} / \mathrm{dL}$, kreatinin 2,9 mg/dL. Pemeriksaan dengan pewarnaan Gram pada sediaan yang diambil dari ulkus memperlihatkan adanya PMN kokus Gram positif, kokus Gram negatif, sedangkan school of fish dan tes patergi negatif. Hasil pemeriksaan serologik untuk IgM anti HSV-1 (-), IgG anti HSV-1 (+), IgM dan IgG anti HSV-2 (+). Hasil pemeriksaan VDRL dan TPHA (-).

Diagnosis banding untuk pasien ini ialah ulkus mole dan sifilis stadium I sedangkan diagnosis akhir ialah AB koinfeksi dengan herpes genitalis rekuren. Diagnosis dari Bagian Interna ialah gastropati uremikum dengan diagnosis banding diabetikum, diabetes melitus tipe 2 , congestive heart failure $f c 2$ et causa hypertension heart disease dengan diagnosis banding coronary artery disease, hiperensi terkontrol, chronic kidney disease et causa hipertensi nefrosklerosis dengan diagnosis banding diabetic kidney disease.

Penatalaksanaan non medikamentosa ialah menjelaskan tentang penyakit dan faktor-faktor pencetusnya serta menjelaskan bahwa kemungkinan penyakit dapat berulang kembali. Penatalaksanaan medikamentosa ialah asiklovir 5 x $200 \mathrm{mg} / \mathrm{hari}$ selama 5 hari, dental paste triamsinolon asetonid $0,1 \%$ (untuk luka di dalam mulut), kompres terbuka dengan $\mathrm{NaCl} 0,9 \% 3 \times 30$ menit. Terapi dari Bagian Penyakit Dalam ialah IVFD NaCL 0,9\% : EAS Primer = 1:1, $14 \mathrm{gtt} /$ menit, Novorapid® ${ }^{\circledR} 3 \mathrm{x} 4 \mathrm{IU}$ bila kadar gula darah $>200 \mathrm{mg} / \mathrm{dL}$, asam folat $2 \times 400 \mathrm{mg}$, bikarbonas natrikus $3 \times 500 \mathrm{mg}$, amlodipin $5 \mathrm{mg} 1-0-0$, ranitidin $2 \times 50 \mathrm{mg}$, Nitrokaf Retard 2x2,5 mg kapsul, simvastatin $20 \mathrm{mg} 0-0-1$, alopurinol 100 mg 0-0-1, klindamisin 3x300 mg kapsul, asam fusidat krim 2xoles, parasetamol $3 \times 500 \mathrm{mg}$, asam traneksamat 3x500 mg.

Prognosis pasien ini ialah quo ad vitam bonam, quo ad functionam bonam, quo ad sanationam dubia. 


\section{BAHASAN}

Adamantiades-Behçet merupakan penyakit kronis dengan relaps yang tergolong dalam vaskulitis sistemik. Penyebabnya tidak diketahui, meskipun terdapat dugaan bahwa mekanisme imun (autoimun) dan faktor genetik (HLA-B5 dan HLA-DR5 alloantigen) berperan pada penyakit ini. Beberapa organism patogen seperti HSV-1 dan Streptococcus sanguis dapat pula menjadi faktor pencetus. Manifestasi klinis yang paling sering berupa ulkus oral rekuren, ulkus genital rekuren, lesi kulit, lesi okular dan artritis/artropati. Dapat juga ditemukan gangguan vaskuler, gastrointestinal, neurologi, psikiatri, paru, ginjal, jantung, epididimitis, serta gejala lainnya. ${ }^{1}$

Infeksi herpes simpleks merupakan kelainan pada daerah orolabial (herpes orolabial) serta daerah genital dan sekitarnya (herpes genitalis) yang disebabkan oleh HSV dengan gejala khas berupa vesikel berkelompok diatas dasar eritema dan bersifat rekuren. Herpes genitalis terutama disebabkan oleh HSV-2. Tergantung dari cara berhubungan seksual maka herpes genitalis juga dapat disebabkan oleh HSV1, dan sebaliknya herpes labialis juga dapat disebabkan oleh HSV-2. ${ }^{7}$

Adamantiades-Behçet biasanya dimulai pada usia 30-40 tahun. Rasio laki-laki dan perempuan hampir sama tetapi laki-laki sering memiliki gejala yang lebih berat. ${ }^{1}$ Herpes simpleks virus menyerang baik laki-laki maupun perempuan dengan frekuensi yang tidak jauh berbeda, dan biasanya terjadi pada dekade II atau III, serta berhubungan dengan peningkatan aktivitas seksual. $^{7}$

Pasien ini seorang laki-laki berusia 72 tahun dengan keluhan luka-luka di dalam mulut dan kelamin yang terasa nyeri sejak 1 minggu yang lalu, yang timbulnya hampir bersamaan dan terdapat riwayat demam. Keluhan luka pada mulut dan kelamin ini sudah sekitar 4 kali dialami oleh pasien sejak 3 tahun terakhir dan kedua luka ini timbul hampir selalu bersamaan. Riwayat adanya lepuh-lepuh di mulut dan kelamin sebelumnya diragukan pasien. Selain itu, terdapat riwayat promiskuitas dengan pasangan seks di luar pernikahan.

Manifestasi klinis yang paling sering pada pasien dengan $\mathrm{AB}$ yaitu ulkus aftosa pada mulut dan genital yang berulang, lesi multipel, nyeri, diameter $1-3 \mathrm{~cm}$, batas tegas, dasar tertutup jaringan fibrin, serta sekitar lesi eritem. ${ }^{1}$ Manifestasi klinis pada herpes genitalis yaitu ditemukan vesikel berkelompok, pustul, dan ulkus eritem. ${ }^{9}$ Pada kasus ini, manifestasi klinis yang ditemukan ialah adanya ulkus aftosa yang multipel, bentuk bulat, diameter $\pm 0,5-1 \mathrm{~cm}$, batas tegas, dasar tertutup jaringan fibrin. Sekitar ulkus tampak kemerahan, dengan erosi dan krusta di region labialis. Pada regio glans penis terdapat ulkus dangkal, multipel, bentuk tidak beraturan, ukuran bervariasi $\pm 1 \times 2 \times 0,2 \mathrm{~cm}$, lesi yang punch out, dan adanya erosi. Ulkus dangkal tersebut berasal dari vesikel, berisi cairan jernih, berkelompok, yang kemudian pecah. Sebelum timbul lesi kulit, biasanya didahului rasa terbakar dan gatal di daerah lesi. Setelah lesi timbul dapat disertai gejala konstitusi seperti malaise, demam dan nyeri otot. Lesi kulit berbentuk vesikel yang berkelompok dengan dasar eritem. Vesikel ini mudah pecah dan menimbulkan erosi atau ulkus dangkal yang multipel.

Pemeriksaan laboratorium pada $\mathrm{AB}$ tidak spesifik. ${ }^{5}$ Terdapat perubahan nilai limfosit dan neutrofil yang ditandai dengan meningkatnya jumlah leukosit seperti pada kasus ini disertai dengan anemia. Pemeriksaan laboratorium lain dalam batas normal dan tidak ditemukan keterlibatan sistemik.

Pemeriksaan khusus berupa tes patergi dilakukan dengan pemberian trauma minor (prick) pada kulit menggunakan jarum 20gauge atau injeksi larutan garam fisiologis $(\mathrm{NaCl})$ sebanyak $0,1 \mathrm{ml}$ secara intrakutan tanpa disinfeksi sebelumnya. Skin prick dilakukan dengan sudut $45^{\circ} \mathrm{C}$ atau 3-5 mm intrakutan pada daerah volar lengan. Timbulnya papul atau pustul dalam 24-48 jam pada area injeksi dianggap sebagai hasil positif dan memiliki spesifi-sitas 98,4\% untuk AB. ${ }^{1,6}$ Pemeriksaan histopatologik pada $\mathrm{AB}$ menunjukkan gambaran vaskulitis leukositoklastik, trombosis, infiltrasi netrofil perivaskular dengan 
endothelial swelling, dan ekstravasasi eritrosit. ${ }^{1,5}$

Pada kasus ini terdapat leukositosis (hitung leukosit $10.720 / \mu \mathrm{L}$ ) dan anemia ringan (kadar hemoglobin 9,7 $\mathrm{g} / \mathrm{dL}$ ), sedangkan hasil tes patergi negatif. Pemeriksaan histopatologik tidak dilakukan mengingat usia pasien dan keadaan umumnya lemah. Pada herpes genitalis, pemeriksaan serologis antibodi terhadap HSV 1 dan 2 berupa $\operatorname{IgM}$ dan $\operatorname{IgG}$ anti HSV-1 dan HSV-2. Pemeriksaan serologis pada pasien ini menunjukkan anti HSV-1 IgM (negatif), anti HSV-1 IgG (positif), anti HSV-2 IgM (positif), dan anti HSV-2 $\operatorname{IgG}$ (positif). ${ }^{12-14}$

Diagnosis Adamantiades-Behçet ditegakkan berdasarkan International Criteria for Behçet Disease (ICBD) yaitu lesi berulang di mata berupa uveitis atau vaskulitis retina, ulkus di mulut yang berulang setidaknya $3 \mathrm{x}$ dalam 12 bulan, dan ulkus genital (lokasi penis, skrotum, vagina, labia, anal, perianal); jika positif masing-masing diberi skor 2. Lesi kulit berulang seperti eritema nodosum, pseudofolikulitis atau lesi papulopustular, manifestasi sistem saraf pusat, vaskular (vaskulitis, varises, aneurisma), dan tes patergi positif masing-masing diberi skor 1 . Apabila skor $\geq 4$ diagnosis maka diagnosis AB dapat ditegakkan. ${ }^{1,4}$ Pada kasus ini skor ICBD yang didapat ialah 4 terdiri dari ulkus pada mulut yang hilang timbul, nyeri, sudah berulang $4 \mathrm{x}$ dalam 1 tahun terakhir, dan ulkus berulang di glans penis, sehingga kasus ini didiagnosis sebagai $\mathrm{AB}$.

Untuk menegakkan diagnosis kasus herpes genitalis, bila memungkinkan ditunjang dengan pemeriksaan laboratorium berupa tes Tzank, kultur, dan pemeriksaan serologik. ${ }^{7}$ Tes Tzank merupakan pemeriksaan laboratorium yang paling sederhana dengan pengecatan Giemsa atau Wright, dimana akan terlihat sel raksasa berinti banyak. $^{13}$ Spesimen untuk pemeriksaan diambil dari vesikel; oleh karena itu pemeriksaan Tzank tidak dilakukan pada kasus ini karena sudah tidak terdapat lesi vesikel. Pemeriksaan yang paling sensitif ialah dengan cara kultur, mengingat sebagian kasus dapat memiliki gejala yang tidak khas. Namun, pemeriksaan ini belum tersedia secara luas sehingga tidak dilakukan. Pemeriksaan yang dilakukan ialah pemeriksaan serologik anti HSV-1 dan 2, IgM dan IgG. ${ }^{13,14}$ Sebelum diagnosis ditegakkan, lesi ulkus pada $\mathrm{AB}$ didiagnosis banding dengan herpes genitalis. Pada AB ditemukan ulkus oral rekuren dan ulkus genital rekuren yang nyeri. Pada herpes genitalis rekuren/sekunder terdapat ulkus multipel yang biasanya didahului dengan vesikel bergerombol dan mudah pecah. Pasien ini didiagnosis akhir sebagai Adamantiades Behçet koinfeksi dengan herpes genitalis rekuren berdasarkan skor ICBD 4, gambaran klinis yang sesuai dengan lesi herpes genitalis rekuren, antibodi IgG dan IgM HSV-2 yang positif, serta gambaran klinis yang menunjang untuk herpes genitalis. ${ }^{1}$

Pasien ini tergolong usia lanjut atau geriatri yang mudah mengalami penurunan status imun atau immunosenescence. Immunosenescence merupakan suatu proses kompleks yang ditandai dengan penurunan fungsi sistem imun seseorang seiring bertambahnya usia. Gangguan sistem imun yang terjadi, terutama sistem imun seluler, yang dapat memengaruhi manifestasi klinis dan rekurensi infeksi HSV. ${ }^{11}$

Penatalaksanaan AB tergantung lokasi dan derajat keparahan. ${ }^{1}$ Terapi topikal dapat berupa bahan kaustik (perak nitrat 1$2 \%$, hidrogen peroksida $0,5 \%$ ), antiseptik atau obat antiinflamasi topikal (obat kumur klorheksidin 1-2\%, triklosan 0,1\%), kortikosteroid topikal 4 kali per hari, anestesi topikal (lidokain 2-5\%) 2-3 kali per hari untuk mengurangi rasa nyeri. Dapat diberikan kombinasi steroid topikal dan antibiotik topikal selama 7 hari pada kasus yang ringan. Terapi herpes genitalis rekuren yaitu asiklovir 200mg per oral $5 x$ sehari selama 5 hari dan terapi simtomatis. ${ }^{15}$ Pasien diberikan tablet asiklovir 5x200 mg selama 5 hari, kompres terbuka dengan $\mathrm{NaCl} 0,9 \% \quad 3 \times 30$ menit untuk perawatan luka, krim asam fusidat 2xoles /hari untuk luka di daerah kelamin, dan dental pasta triamsinolon asetonid 2 kali oles sehari 
untuk luka di mulut. Menurut acuan pustaka, ulkus oral biasanya mengalami penyembuhan spontan dalam 4 hari hingga 1 bulan, sedangkan ulkus genital bertahan lebih lama. Evaluasi pada hari ke-3 menunjukkan perbaikan, terutama lesi di mulut (Gambar 2). Pada evaluasi hari ke-10 ditemukan ulkus di mulut dan ulkus di

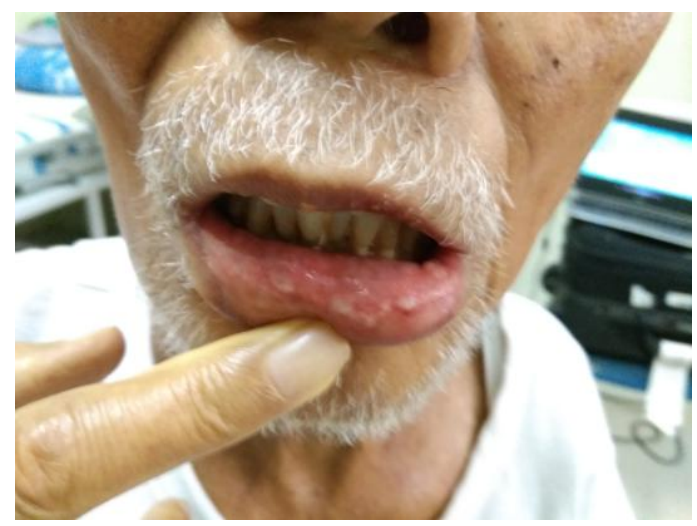

Gambar 1. Pemeriksaan hari ke-1.

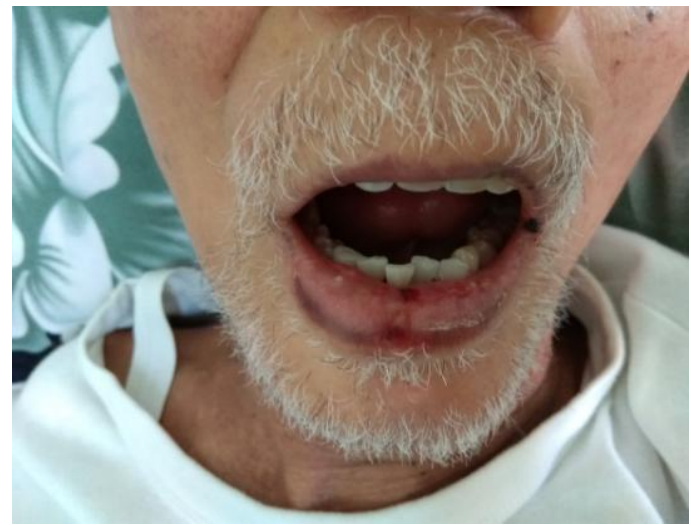

Gambar 2. Pemeriksaan hari ke-5
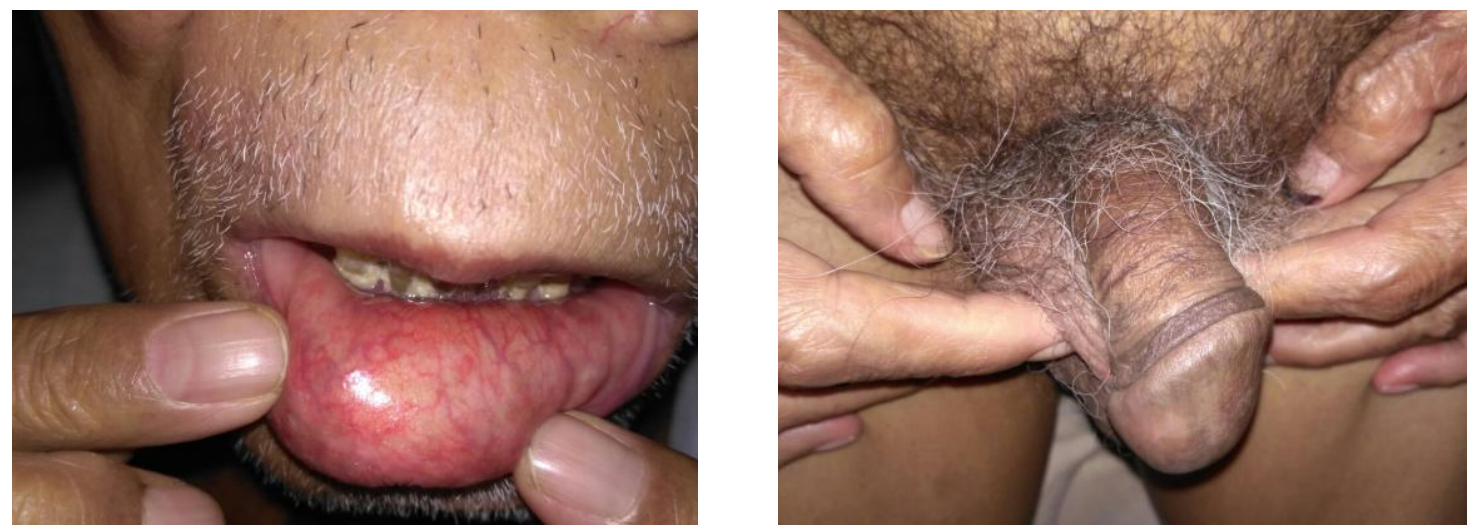

kelamin sembuh (Gambar 3). Sepuluh hari paska pengobatan, pasien telah mengalami perbaikan.

Prognosis pada kasus ini quo ad vitam quo ad functionam ad bonam, quo ad sanationam dubia karena kedua penyakit tersebut bisa terjadi rekurensi.
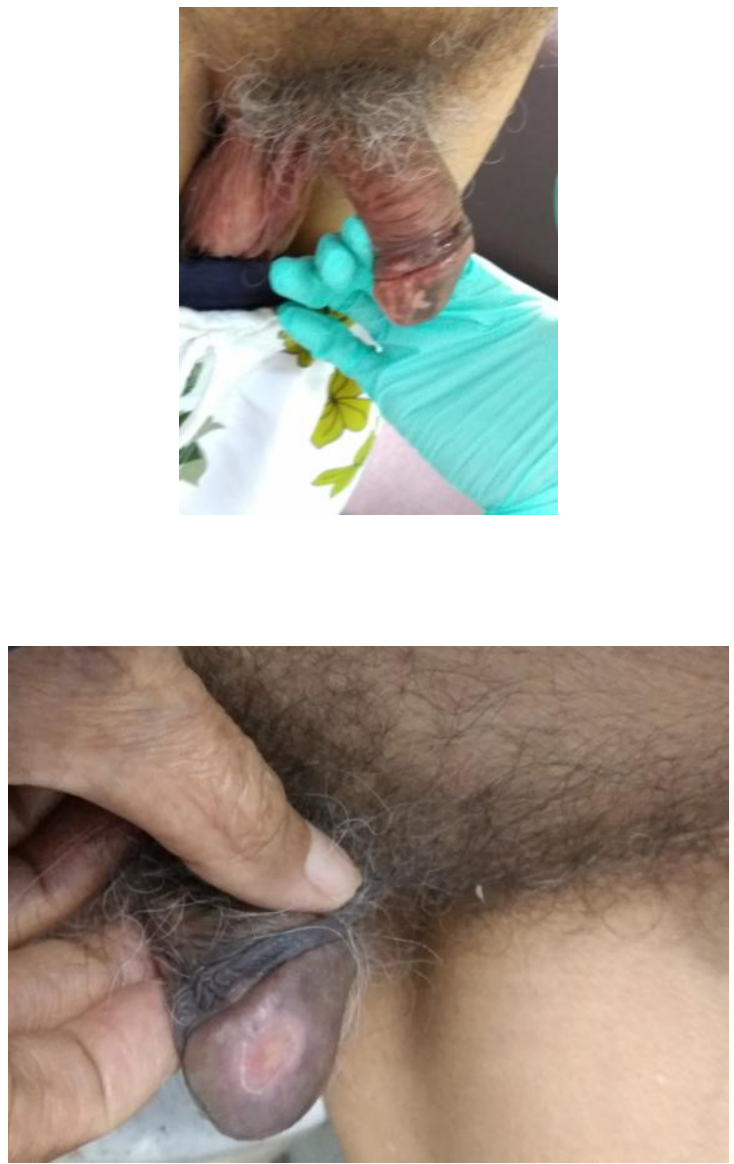

Gambar 3. Pemeriksaan hari ke-10 
DAFTAR PUSTAKA

1. Zouboulis CC. Adamantiades-Behçet disease. In: Goldsmith LA, Katz SI, Gilchrest BA, Paller AS, Leffell DJ, Wolff K, editors. Fitzpatrick's Dermatology in General Medicine (8th ed). New York: McGraw Hill, 2012; p. 2033-42.

2. Addimanda O, Pazzola G, Pipitone N, Salvarani C. Epidemiology of Behçet syndrome. In: Emmi L, editor. Behçet's Syndrome from Pathogenesis to Treatment. Milan: Springer, 2014; p. 17-24.

3. Türsen Ü. Pathophisiology of the Behçet's disease. Pathology Research Inter national. 2012. doi:10.1155/2012/ 493015.

4. Kronborg C, Mahar PD, Kelly R. Should we keep changing the diagnostic criteria for Behçet disease? Dermatology. 2014; 228:1-4.

5. Alnaimat FA, Diamond HS, Lisse JR. Behçet disease. emedicine journal. 2014. Available from: emedicine. medscape.com.

6. Sequeira FF, Daryani D. The oral and skin pathergy test. Indian J Dermatol Venereol Leprol. 2011;77(4):526-30.

7. Daili SF. Herpes genitalis pada immunekompromais. In: Daili SF, Makes WIB, editors. Infeksi Virus Herpes. Jakarta: Balai Penerbit FKUI, 2002; p. 89-99.

8. Saiful SF. Herpes genitalis. In: Daili SF, Makes WIB, Zubier F, editors. Infeksi
Menular Seksual (4th ed). Jakarta: Balai Penerbit FKUI, 2014; p.125-39.

9. Marques AR, Cohen JI. Herpes simplex. In: Goldsmith LA, Katz LI, Gilchrest BA, Paleer AS, Leffel DJ, Wolff K, editors. Fitzpatrick's Dermatology in General Medicine (8th ed). New York: McGraw Hill Companies, 2012; p. 2367-82.

10. Lawrency C, Wald A. Genital herpes. In: Holmes KK, Sparling PF, Cox N, Stamm W, editors. Sexually Transmitted Disease (4th ed). New York: McGraw Hill, 2008; p. 399-429.

11. Gruver AL, Hudson L, Sempowski GD. Immunosenescense of ageing. J Pathol. 2007;211(2):144-56.

12. Murtiastutik D, Barakbah J, Lumintang H, Martodihardjo S. Buku Ajar Infeksi Menular Seksual. Surabaya: Airlangga University Press, 2008.

13. LeGoff J, Pere H, Belec L. Diagnosis of genital herpes simplex virus infection in the clinical laboratory. Virol $\mathrm{J}$. 2014;11:83.

14. Singh A, Preiksaitis J, Romanowski B. The laboratory diagnosis of herpes simplex virus infections. Can J Infect Dis Med Microbiol. 2005;16(2):92-8.

15. Kementerian Kesehatan RI Direktorat Jenderal Pengendalian Penyakit dan Penyehatan Lingkungan. Pedoman nasional penanganan infeksi menular seksual 2011. Jakarta: Direktur Jenderal PP dan PL, 2011. 